\author{
Franciszek Mróz \\ https://orcid.org/0000-0001-6380-387X \\ Uniwersytet Pedagogiczny w Krakowie \\ Instytut Geografii \\ Zakład Turystyki i Badań Regionalnych \\ franciszek.mroz@up.krakow.pl
}

\title{
PRZEMIANY W TURYSTYCE RELIGIJNEJ W POLSCE NA POCZĄTKU XXI WIEKU
}

\begin{abstract}
Abstrakt: W opracowaniu opisano przemiany, które zaszły w turystyce religijnej w Polsce na początku XXI w. Zaliczono do nich przede wszystkim rozwój sieci ośrodków i tras pielgrzymkowych, renesans średniowiecznych szlaków pątniczych, niesłabnącą popularność pieszego pielgrzymowania, nowe formy pielgrzymowania i turystyki religijnej - pielgrzymki rowerowe, kajakowe, morskie, narciarskie, konne, nordic walking, biegowe, na hulajnogach, rolkach i nartorolkach. W przestrzeni pielgrzymkowej Polski obserwuje się rosnące zainteresowanie "wakacjami” i urlopami w klasztorach, pustelniach oraz domach rekolekcyjnych, a także stały wzrost weekendowej turystyki religijnej. Turystów religijnych oraz pielgrzymów przyciągają do sanktuariów - oprócz stałych nabożeństw i uroczystości religijnych - organizowane w nich obrzędy, misteria, odpusty i święta religijne.
\end{abstract}

Słowa kluczowe: turystyka religijna, pielgrzymki, sanktuarium, szlaki pielgrzymkowe, Droga św. Jakuba.

\section{WSTĘP}

Turystyka religijna jest jedną z najbardziej rozwijających się form ruchu turystycznego na świecie. Według danych Światowej Organizacji Turystyki (UNWTO) z 2014 r. rocznie około $330 \mathrm{mln}$ osób podejmuje podróże o charakterze religijnym lub religijno-poznawczym do głównych ośrodków pielgrzymkowych na świecie (Tourism can protect and promote religious heritage, 2014). Wyraźny rozkwit turystyki religijnej na świecie $\mathrm{w}$ ostatnim 30-leciu jest spowodowany wieloma czynnikami, przede wszystkim: religijnymi, historycznymi, ekonomicznymi, geograficznymi, społeczno-kulturowymi i politycznymi. Na rozwój ten wpływ ma promocja sanktuariów, renesans średniowiecznych i powstanie nowych szlaków pielgrzymkowych, rozwój motoryzacji, a także rozbudowa infrastruktury turystycznej w ośrodkach pielgrzymkowych. Rosnącej popularności tego typu podróży nie osłabia nasilone zjawisko sekularyzacji życia publicznego i postępujący proces laicyzacji społeczeństw na świecie (Jackowski, 2003, s. 123-124).

Polskę zalicza się do krajów o największym potencjale rozwoju pielgrzymek i turystyki religijnej na świecie. Jest to rezultat stale rozwijającej się sieci szlaków pielgrzymkowych i sanktuariów, wielowiekowych tradycji pątniczych, działalności przedsiębiorczej opiekujących się danymi sanktuariami (kustoszy, grup, stowarzyszen, zgromadzeń zakonnych), wzbogacania programu duszpasterskiego w sanktuariach, promocji sanktuariów, wa- lorów historycznych, kulturowych i architektonicznych świątyń sanktuaryjnych, poprawy dostępności komunikacyjnej, rozwoju motoryzacji oraz rozbudowy infrastruktury turystycznej i pielgrzymkowej.

Opracowanie ma charakter przeglądowy, a jego głównym celem było wskazanie głównych trendów i przemian $\mathrm{w}$ turystyce religijnej i pielgrzymowaniu w Polsce na początku XXI w. Warto w tym miejscu zaznaczyć, że w tym czasie nastąpiło wiele wydarzeń, które odcisnęły piętno na przemianach $w$ ruchu pielgrzymkowym oraz $\mathrm{w}$ turystyce religijnej $\mathrm{w}$ Polsce: ostatnia pielgrzymka Jana Pawła II do Polski (16-19.08.2002 r.), wejście Polski do Unii Europejskiej (1.05.2004 r.), śmierć Jana Pawła II (2.04.2005 r.), pielgrzymka papieża Benedykta XVI do Polski (25-28.05.2008 r.), przystąpienie Polski do strefy Schengen (21.12.2007 r.), beatyfikacje i kanonizacje nowych polskich błogosławionych i świętych, Nadzwyczajny Jubileusz Miłosierdzia (8.12.2015 r. - 20.11.2016 r.), obchody 1050. rocznicy chrztu Polski, a także Światowe Dni Młodzieży w Krakowie (26-31.07.2016 r.) z udziałem papieża Franciszka oraz 2,5-milionowej rzeszy młodzieży ze 187 krajów świata (Pokojska, Pudełko, 2016, s. 26-27). $\mathrm{W}$ pracy uwzględniono przemiany zachodzące $\mathrm{w}$ turystyce religijnej wyłącznie w odniesieniu do ośrodków i szlaków pielgrzymkowych Kościoła katolickiego.

Prezentowane opracowanie jest rezultatem badań kameralnych i terenowych, które autor prowadzi od $1995 \mathrm{r}$. 
w przestrzeni pielgrzymkowej Polski. Badania terenowe zostały przeprowadzone $\mathrm{w} 400$ sanktuariach oraz na 22 odcinkach Camino de Santiago w Polsce, na kilkunastu odcinkach szlaków papieskich oraz na transgranicznym Szlaku Maryjnym „Światło ze Wschodu”. W ramach badań terenowych przeprowadzono obserwacje, wywiady pogłębione z kustoszami sanktuariów oraz kwerendę $\mathrm{w}$ archiwach i bibliotekach sanktuaryjnych (m.in. analizę ksiąg pielgrzymkowych). W opracowaniu zebranych wyników badań posłużono się metodami: opisowo-analityczną, dynamiczno-porównawczą oraz kartograficznymi.

\section{PRZEMIANY W SIECI OŚRODKÓW I SZLAKÓW PIELGRZYMKOWYCH W POLSCE NA POCZĄTKU XXI W.}

Współczesna sieć sanktuariów w Polsce jest dziedzictwem wielowiekowej tradycji i wyrazem pobożności ludowej pokoleń wiernych. Tworzą ją sanktuaria Kościoła katolickiego obrządku łacińskiego, bizantyjsko-ukraińskiego, ormiańskiego i bizantyjsko-słowiańskiego, Kościoła prawosławnego, a także ośrodki pielgrzymkowe wyznawców judaizmu (m.in. Kraków, Leżajsk, Bobowa, Nowy Sącz) oraz islamu (Bohoniki i Kruszyniany). Obecnie (stan na 1 czerwca 2019 r.) w Polsce rejestruje się ponad 800 sanktuariów i ośrodków pielgrzymkowych. Wśród nich zdecydowanie dominują sanktuaria katolickie (rys. 1).

Konieczne jest $\mathrm{w}$ tym miejscu zwrócenie uwagi na ważny aspekt ustalenia liczby funkcjonujących w Polsce sanktuariów. Autor prezentowanego opracowania od ponad 20 lat prowadzi w tym zakresie (głównie w odniesieniu do sanktuariów Kościoła katolickiego) szczegółowe badania i kwerendę schematyzmów oraz czasopism diecezjalnych. Lista sanktuariów Kościoła katolickiego została w 2018 r. zweryfikowana na podstawie konsultacji z kanclerzami wybranych kurii oraz wykazów sanktuariów w poszczególnych diecezjach (materiały te autor otrzymał ze wszystkich kurii metropolitalnych i diecezjalnych Kościoła rzymskokatolickiego w Polsce). W wyniku tych konsultacji, kwerendy oraz na podstawie aktualnych wykazów sanktuariów poszczególnych diecezji można stwierdzić, że obecnie w Polsce rejestruje się ponad 790 sanktuariów katolickich - są to sanktuaria legitymujące się w dniu 1 czerwca 2019 r. erygującym je dekretem biskupim, a także ośrodki, które w urzędowych wykazach poszczególnych diecezji oraz w dokumentach ordynariusza obiektu zostały określone mianem ",sanktuarium" ${ }^{1}$. Istotnym problem jest bowiem fakt, że ponad połowa ośrodków pielgrzymkowych Kościoła katolickiego w Polsce, które są nazywane sanktuariami, nie posiada stosownego dekretu określonego przepisami Kodeksu prawa kanonicznego (1984, kan. 1230). Jednak ze względu na wielowiekową tradycję pielgrzymowania, uroczystości odpustowe oraz znaczną liczbę przybywających do tych miejsc pielgrzymów zyskały one miano sanktuariów i za takie uznawane są w oficjalnych wykazach diecezjalnych (Bagiński, Kamiński, Opaliński, 2012). Na liście ośrodków pielgrzymkowych w diecezji drohiczyńskiej znalazło się 14 sanktuariów i 7 kościołów szczególnego kultu. Dodatkowo bardzo często ośrodki takie pełnią te same funkcje co sanktuaria, mając oficjalną aprobatę władz kościelnych. W Dyrektorium o pobożności ludowej i liturgii. Zasady i wskazania (2003, s. 187) podkreśla się, że ośrodki takie „stanowią część «geografii» wiary i pobożności ludu Bożego, społeczności, która mieszka na określonym terytorium i która w duchu wiary pielgrzymuje do niebieskiego Jeruzalem".

W grupie katolickich sanktuariów ponad 520 ośrodków (tj. ok. 70\% ogółu) stanowią sanktuaria maryjne, spośród których 239 szczyci się posiadaniem wizerunku Matki Bożej koronowanego na prawie papieskim, tj. „w imieniu i powagą Papieża”, po otrzymaniu stosownego zezwolenia od Kongregacji Kultu Bożego. Pozostałe sanktuaria katolickie są związane $\mathrm{z}$ kultem Jezusa Chrystusa i Trójcy Świętej (sanktuaria Pańskie - 104 ośrodki) oraz kultem świętych i błogosławionych (ponad 150 sanktuariów) (por. Datko, 2014; Mróz, 2016).

Warto również podkreślić, że od początku $2001 \mathrm{r}$. do 1 czerwca 2019 r., zgodnie z przepisem kanonu 1230 Kodeksu prawa kanonicznego... (1984), na mocy dekretu ordynariuszy miejsc/obiektów zostało erygowanych ponad 250 nowych sanktuariów Kościoła katolickiego (por. Mróz, Mróz, 2018). Choćby tylko z tego względu najnowsze publikacje $w$ literaturze przedmiotu, odwołujące się do liczby sanktuariów w Polsce na początku XXI w., niestety uznać należy za nieaktualne (por. Jackowski, Bilska-Wodecka, Sołjan, 2014). Największy wzrost procentowy nowych sanktuariów w XXI w. odnotowano w grupie sanktuariów świętych i błogosławionych oraz sanktuariów Pańskich. W analizowanym okresie na mocy dekretu miejscowych ordynariuszy powstało bowiem 90 sanktuariów świętych i błogosławionych (tj. blisko $60 \%$ ogółu tego typu sanktuariów w Polsce) i 32 sanktuaria Pańskie (ponad 30\% ogółu Pańskich loca sacra). Erygowanie nowych sanktuariów świętych i błogosławionych w Polsce należy wiązać przede wszystkim $\mathrm{z}$ obserwowanym $\mathrm{w}$ wielu ośrodkach renesansem kultu świętych cieszących się w średniowieczu i w okresie odnowy potrydenckiej wielką czcią wśród wiernych - m.in. św. Józefa (w Bolesławowie, Częstochowie, Kielcach, Nisku, Prudniku, Rudzie Śląskiej, Siedlcach, Słupsku i Wadowicach), św. Jakuba (w Brzesku, Jakubowie, Lęborku, Małujowicach, Szczyrku i Więcławicach Starych), św. Franciszka z Asyżu (w Jutrzynie), św. Antoniego (w Chełmie, Ostrołęce, Ratowie, Suszu, Warszawie), św. Floriana (w Chorzowie), św. Stanisława Biskupa Męczennika (Piotrawinie), św. Barbary (w Strumieniu), 
św. Kazimierza Królewicza (w Krakowie), św. Kingi (w Nowym Korczynie), św. Jacka (w Legnicy), bł. Salomei (w Grodzisku k. Skały), św. Idziego (w Wyszkowie), św. Huberta (w Żołędowie) oraz św. Rocha (w Miks- tacie, Osieku) (por. Mróz, Mróz, 2018). Powstanie nowych sanktuariów świętych i błogosławionych jest także następstwem kanonizacji i beatyfikacji licznej grupy Polek i Polaków oraz rozwijającego się w Kościele

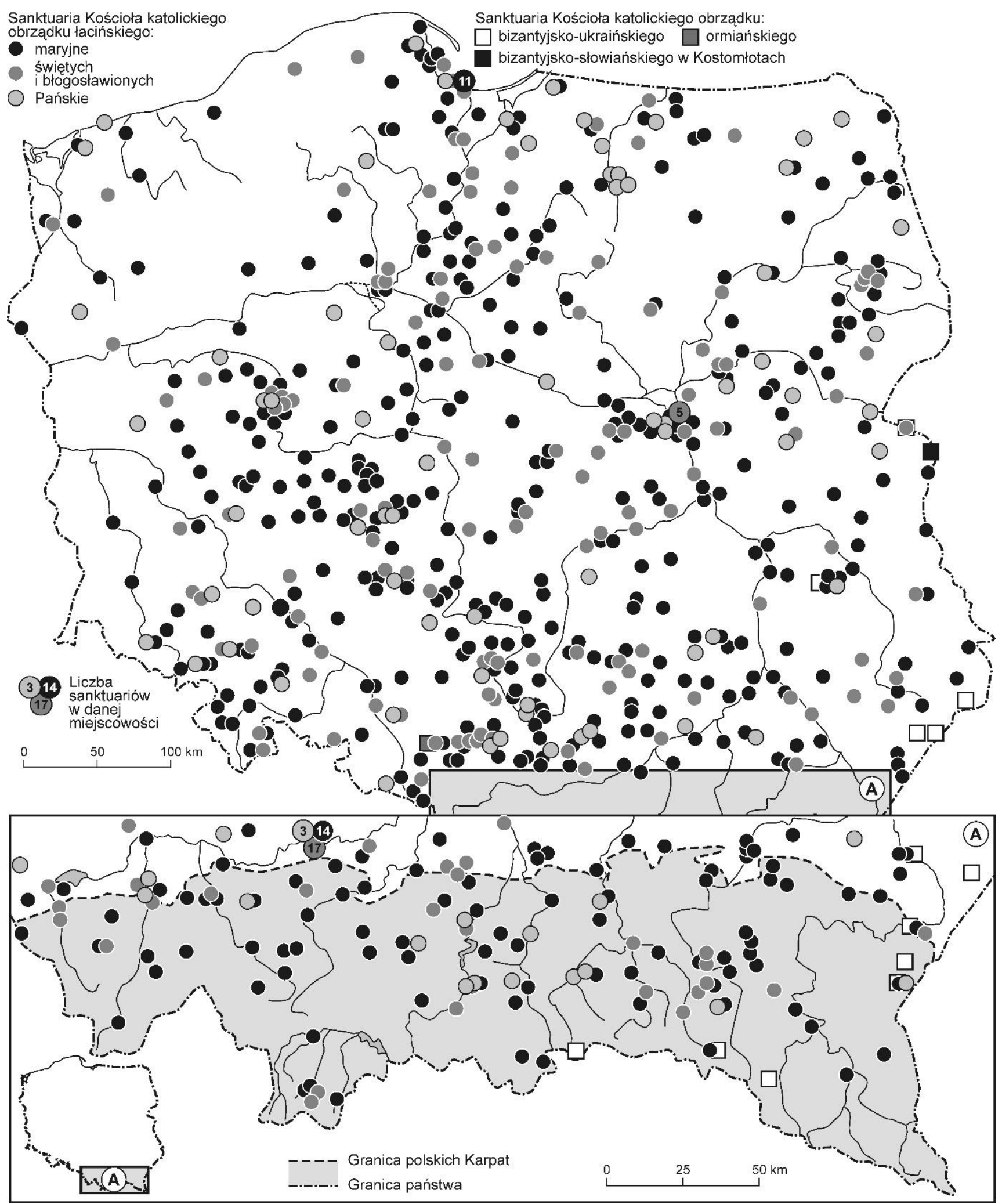

Rysunek 1. Sanktuaria Kościoła katolickiego w Polsce (stan na 1 czerwca 2019 r.) 
katolickim nabożeństwa do „popularnych” świętych - jak np. św. ojca Pio (w Terliczce, Przeprośnej Górce i Warszawie), św. Rity (w Nowym Sączu) oraz Świętych Dzieci Fatimskich - Franciszka i Hiacynty Marto (w Szczecinie i Pajęcznie).

Wśród sanktuariów Pańskich powstałych po $2000 \mathrm{r}$. najliczniejszą grupę stanowią sanktuaria Miłosierdzia Bożego (w sumie 18 ośrodków: Gdańsk-Wrzeszcz, Łódź, Poznań, Kielce, Sosnowiec, Ostrowiec Świętokrzyski, Toruń, Biała Podlaska, Ełk, Świdnica, Świebodzin, Sokołów Podlaski, Olsztyn-Nagórki, Olsztyn-Zatorze, Zawiercie-Blanowice, Ostrów Wielkopolski, Suwałki i Bielsk Podlaski), a także sanktuaria Męki Pańskiej (sanktuaria relikwii Drzewa Krzyża Świętego w Jeleniej Górze, Klebarku Wielkim, Rększowicach i Wałbrzychu, sanktuarium Krzyża Świętego w Pustkowie oraz sanktuaria Męki Pańskiej w Praszce, Serpelicach, Tyńcu Legnickim i Ziębicach). W XXI w. powstały także dwa sanktuaria Najświętszego Serca Pana Jezusa - w Dąbrowie Górniczej Strzemieszycach i Warszawie oraz bardzo znane w północno-wschodniej Polsce sanktuarium Najświętszego Sakramentu w Sokółce.

W XXI w. zostało erygowanych ponad 130 sanktuariów maryjnych w Polsce. Należy jednak podkreślić, że od początku 2001 r. do 1 czerwca 2019 r. dokonano 39 koronacji papieskich oraz ponad 90 koronacji biskupich wizerunków Matki Bożej. Biorąc pod uwagę wezwanie maryjnych loca sacra powstałych od 2001 r., najliczniejszą grupę stanowią sanktuaria: Matki Bożej Pocieszenia, Matki Bożej Fatimskiej, Matki Bożej Nieustającej Pomocy, Matki Bożej Szkaplerznej oraz Matki Bożej Bolesnej.

Obecnie w Polsce funkcjonuje 10 chrześcijańskich ośrodków pielgrzymkowych o randze międzynarodowej. $W$ tej grupie dziewięć to sanktuaria Kościoła katolickiego (sanktuaria: Matki Bożej Częstochowskiej na Jasnej Górze, pasyjno-maryjne w Kalwarii Zebrzydowskiej, Bożego Miłosierdzia w Krakowie-Łagiewnikach, św. Jana Pawła II na Białych Morzach w Krakowie, św. Maksymiliana Marii Kolbego w Niepokalanowie, św. Anny na Górze Świętej Anny, bł. ks. Jerzego Popiełuszki w Warszawie, Matki Bożej Fatimskiej na Krzeptówkach w Zakopanem oraz miasto Wadowice - miejsce urodzenia św. Jana Pawła II), a jeden ośrodek to prawosławne sanktuarium na Świętej Górze Grabarce. W 2018 r. sanktuaria te odwiedziło w sumie ok. $12 \mathrm{mln}$ osób - najwięcej Jasną Górę (4,5 mln), Kraków-Łagiewniki (ok. 2 mln) oraz Kalwarię Zebrzydowską (1,8 mln). Należy zaznaczyć, że w XXI w. powstały w przestrzeni pielgrzymkowej Polski dwa obiekty pielgrzymkowe, których ranga jest obecnie międzynarodowa - bazylika Bożego Miłosierdzia w Krakowie-Łagiewnikach (konsekrowana i ogłoszona w 2002 r. przez św. Jana Pawła II światowym centrum kultu Bożego Miłosierdzia) oraz sanktuarium św. Jana Pawła II na Białych Morzach w Krakowie.

\section{RENESANS PIELGRZYMEK - WEZDRÓWEK POLAKÓW ŚREDNIOWIECZNYMI SZLAKAMI PIELGRZYMKOWYMI}

W ostatnim 20-leciu w Europie obserwuje się renesans średniowiecznych szlaków peregrinationes maiores - obejmujących podróże religijne do trzech głównych chrześcijańskich loca sacra: sanktuarium Grobu Świętego w Jerozolimie, grobów Apostołów św. Piotra i św. Pawła w Rzymie oraz grobu św. Jakuba Starszego Apostoła - pierwszego męczennika wśród apostołów w Santiago de Compostela (Manikowska, 2002; Onorato, Rizzi, 2017). Największą popularność zyskał szlak pielgrzymkowy do grobu św. Jakuba w Santiago de Compostela - Camino de Santiago. Szlak ten, nazywany często "najpiękniejszą drogą świata" lub "głównym traktem Europy", został w 1987 r. uznany przez Radę Europy za pierwszy Europejski Szlak Kulturowy, a w 1993 i 2015 r. (na terytorium Hiszpanii) oraz w 1998 r. (na obszarze Francji) wpisany na listę światowego dziedzictwa kulturowego i przyrodniczego UNESCO.

W roku 2003 zachodnioeuropejska sieć Camino de Santiago dotarła do granicy niemiecko-polskiej w GörlitzZgorzelcu, dając impuls do oznakowania szlaku na terenie Polski. Pierwszy polski odcinek Szlaku Jakubowego - Dolnośląską Drogę św. Jakuba - otwarto 24 lipca 2005 r. (Mróz, 2015). Obecnie (stan na 1 lipca 2019 r.) 38 polskich odcinków Camino de Santiago, o łącznej długości 6908 km, tworzy sieć najdłuższego szlaku zarówno pielgrzymkowego, jak i kulturowego w Polsce. Sieć ta jest powiązana z europejską siecią szlaków prowadzących do grobu św. Jakuba w Santiago de Compostela, bowiem Droga św. Jakuba w Polsce łączy się z odcinkami Camino de Santiago: w Rosji - w Obwodzie Kaliningradzkim, na Litwie, Ukrainie, Słowacji, w Czechach oraz Niemczech (rys. 2).

Na podstawie przeprowadzonych badań można oszacować, że polskimi odcinkami Drogi św. Jakuba wędruje w ciągu roku około 2 tys. osób. Coraz popularniejsze stają się grupowe wędrówki, szczególnie w ramach inicjatyw pod nazwą "niedzielnego pielgrzymowania Drogą św. Jakuba” lub „weekendu na Drodze św. Jakuba”. Inicjatorami tego typu pielgrzymek są przede wszystkim caminowicze ${ }^{2}$, członkowie bractw św. Jakuba, miłośnicy i przyjaciele Drogi św. Jakuba, członkowie stowarzyszeń związanych z camino, studenci i harcerze (Mróz, 2018b). Na polskich odcinkach Drogi św. Jakuba spotyka się caminowiczów, którzy wędrują pieszo, jadą na rowerach, konno, ale również przemierzają te trasy na nartach (Pielgrzymka Narciarska Beskidzką Drogą św. Jakuba) oraz w kajaku (Kajakowa Pielgrzymka Nyską Drogą św. Jakuba).

Warto zwrócić uwagę na zależność pomiędzy rosnącą liczbą caminowiczów z Polski, którzy otrzymali 


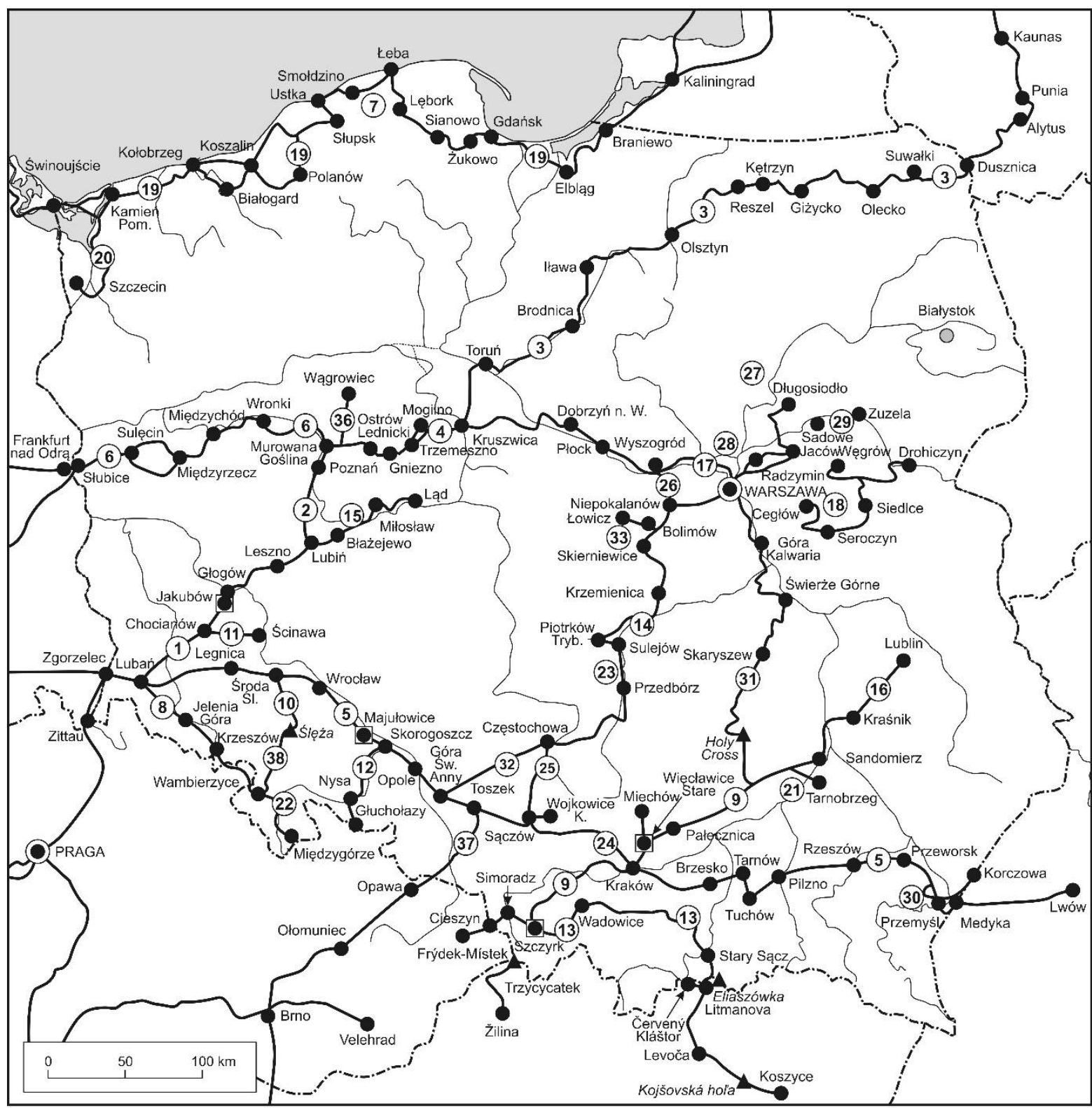

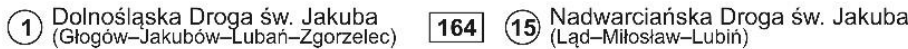

(2) Wielkopolska Droga św Jakuba

234 (16) Lubelska Droga św. Jakuba

(3) Droga Polska (Camino Polaco)

651 Mazowiecka Droga św. Jakuba

651 (Warszawa-Płock-Dobrzyń nad Wisła)

(4) Droga św. Jakuba „Szlak

(5) Droga św. Jakuba Via Regia (Méra św. Anny-Brzeg-Zgorzelec)

6 Lubuska Droga św Jakuba

47 18) Droga św. Jakuba Północno957 (Drohiczyn-Przesmykiesiedlce-Seroczyn-Cegłów)

6) Lubuska Droga św. Jakuba

Leborska Droga św. Jakuba

279 (19) Pomorska Droga św. Jakuba (Via

279 św. Jakuba (Braniewo-Elblagg-Gdańsk-Lębork-

Smołdzino)

(8) Sudecka Droga św. Jakuba

(9) Małopolska Droga św. Jakuba

(10) Ślężańska Droga św. Jakuba

(Ṡlęża-Sobótka-Sroda Śląska)

(11) Miedziana Droga św. Jakuba

(12) Nyska Droga św. Jakuba

122 (20) Słzczecińska Droga św. Jakuba

105 (Swinoujscie-Szczecin)

(21) Tarnobrzeska Droga św. Jakuba

317 (Tarnobrze

22. Kłodzka Droga sw. Jakuba

55 23. Staropolska Droga św. Jakuba

45 (24) Miechowska Droga św. Jakuba

100 (25) Jasnogórska Droga św. Jakuba

(13) Beskidzka Droga św. Jakuba

316 (Eliaszówka-Stary Sacz-Podegrodzie-
Myślenice-Wadowice-Szczyrk-Cieszyn)

14 Warszawska Droga św. Jakuba

(26) Szopenowska Droga św.

(27) Droga Niepodległości św. Jakuba

27) (I. Sadowne-Loretto-Jadów
II. Długosiodło-Wyszów-Jadów-Ossów)

111 28) Droga św. Jakuba „Cudu nad Wisła"

136 (29) Prymasowska Droga św. Jakuba

175 (30) Tuligłowska Droga św. Jakuba

227 (31) Świètokrzyska Droga św. Jakuba

(32) Częstochowska Droga św. Jakuba

(33) Łowicka Droga św. Jakuba

Dobrzyńsko-Kujawska Droga

(34) św. Jakuba (Dobrzyń nad Wisłą-Kruszwica) 33,5

(35) Kaliska Droga św. Jakuba

(36) Wągrowiec-Dąbrówka Kościelna

(37) Śląsko-Morawska Droga św. Jakuba 120

(38) Sowiogórska Droga św. Jakuba

75

(Góra Slęża-Wambierzyce) 
w ostatnim 10-leciu compostela (tj. dokument potwierdzający odbycie pielgrzymki do Santiago de Compostela - przejście pieszo ostatnich $100 \mathrm{~km}$ Camino de Santiago lub przejechanie $100 \mathrm{~km}$ tego szlaku konno bądź $200 \mathrm{~km}$ na rowerze), a zwiększająca się - w tym samym okresie - liczbą kilometrów nowych odcinków Drogi św. Jakuba w Polsce (rys. 3). W 2018 r. w Biurze Pielgrzymkowym Arcybiskupstwa Santiago de Compostela zarejestrowano 4785 Polaków (Estadísticas, 2019). Dla porównania w 2004 r. było to 357 osób z Polski (Estadísticas, 2019). Od początku XXI w. każdego roku średnio ponad 20 osób wyrusza z Polski do Composteli, zgodnie ze średniowiecznym zwyczajem, a więc z progu własnego domu, pokonując pieszo lub rowerem co najmniej 3000 km (Krogmann, Šolcová, Mróz, Mróz, 2013).

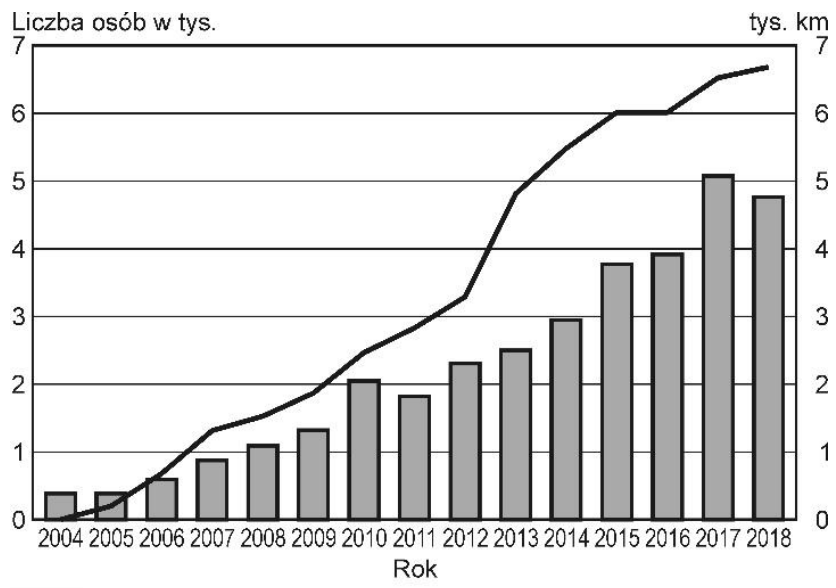

Liczba Polaków, którzy otrzymali compostelę

Długość oznakowanych odcinków Drogi św. Jakuba w Polsce

Rysunek 3. Ruch pielgrzymkowy/turystyczny Polaków do Santiago de Compostela

i rozwój sieci Drogi św. Jakuba w Polsce w latach 2004-2018

Źródło: opracowanie autora

W październiku 2018 r. rozpoczęto w Polsce prace nad wytyczeniem i oznakowaniem polskiego odcinka Drogi do Jerozolimy - Jerusalem Way - najdłuższego na świecie kulturowego szlaku pokoju, który prowadzi przez 15 państw. Długość szlaku z Finisterry w hiszpańskiej Galicji do Jerozolimy wynosi około $7500 \mathrm{~km}$. Z kolei w marcu 2019 r. Uniwersytet Pedagogiczny w Krakowie, Uniwersytet Mikołaja Kopernika w Toruniu oraz gmina Wadowice zostały przyjęte do stowarzyszenia Associazione Europea Romea Strata, którego zadaniem jest odtworzenie i oznakowanie średniowiecznego szlaku pielgrzymkowego pod nazwą Romea Strata, prowadzącego z krajów Europy Środkowo-Wschodniej, tj. Estonii, Łotwy, Litwy, przez kraje Europy Środkowej (Polska, Czechy, Słowacja, Austria, Słowenia) do Wenecji, a następnie do Rzymu.

\section{NOWE SZLAKI PIELGRZYMKOWE W POLSCE}

Imponujący rozwój Camino de Santiago i rosnąca popularność wędrówek tym szlakiem zapoczątkowały proces nazwany przez P. Margry'ego jako „caminonizacja”, tj.

ogólnoświatowy rozwój szlaków świętych lub «duchowych», pobudzony przede wszystkim sukcesem i przywłaszczeniem koncepcji "Camino”. Proces ten obejmuje rozprzestrzenianie idei duchowej drogi, która pobudza ludzi na całym świecie do wyruszenia pieszo w duchową podróż lub refleksyjnego poszukiwania sensu życia (Margry, 2015, s. 186).

W ostatnim 20-leciu w przestrzeni pielgrzymkowej Polski obserwuje się również proces powstawania oraz rozwój nowych szlaków pielgrzymkowych i religijnych. Oprócz wspomnianych już szlaków peregrinationes maiores, na uwagę zasługują przede wszystkim szlaki o randze międzynarodowej (Via Misericordia - Droga Miłosierdzia, Szlak Europejskich Cmentarzy, Szlak Dziedzictwa Żydowskiego, Międzynarodowy Szlak Pielgrzymkowy: Mariazell-Częstochowa, szlak Via Sacra, szlaki papieskie i transgraniczny Szlak Maryjny „Światło ze Wschodu") oraz szlaki świętych i błogosławionych wyniesionych na ołtarze przez św. Jana Pawła II, papieża Benedykta XVI i papieża Franciszka (Mróz, 2014).

Szlaki papieskie obejmują sieć szlaków pieszych (głównie górskich), kajakowych i rowerowych w Polsce, którymi podążał ks. Karol Wojtyła - papież Jan Paweł II. Obecnie na sieć szlaków papieskich składa się kilkanaście odcinków w Karpatach polskich, Sudetach, na Wyżynie Krakowsko-Częstochowskiej, a także na Pojezierzu (Matuszczyk, Własiuk, 2002; Szlaki papieskie $w$ Polsce, 2019).

Idea wytyczenia i oznakowania Międzynarodowej Trasy Pielgrzymkowej - Szlaku Maryjnego (International Pilgrim's Route - St. Mary's Trail, Internationale Pilgerstraße - Marienweg) - łączącej Częstochowę z Mariazell powstała już w latach 90. XX w. w Austrii. Prace nad oznakowaniem polskiego odcinka tego szlaku z Częstochowy do Zakopanego rozpoczęto w 2006 r. Obecnie Międzynarodowa Trasa Pielgrzymkowa łączy narodowe sanktuaria maryjne: Jasną Górę w Polsce, Lewoczę na Słowacji, Mariazell w Austrii oraz Marija Bistrica w Chorwacji.

W sieć szlaków pielgrzymkowych i kulturowych w Polsce wpisuje się wytyczony w 2018 r. transgraniczny Szlak Maryjny "Światło ze Wschodu” (Svätomariánskapút - Svetlo z východu), utworzony w ramach Programu Współpracy Transgranicznej Interreg V-A PolskaSłowacja 2014-2020, współfinansowanego przez Unię Europejską z Europejskiego Funduszu Rozwoju Regionalnego. Na szlaku znajduje się 28 ośrodków pielgrzymkowych, w tym 21 sanktuariów na terenie Polski oraz 7 w Kraju Preszowskim na Słowacji (Mróz, 2018a). 
W 2019 r. Rycerze Kolumba oznakują polski odcinek Drogi Miłosierdzia (Via Misericordia), z Oświęcimia do sanktuarium Miłosierdzia Bożego w Krakowie-Łagiewnikach. Szlak Miłosierdzia powstał w 2016 r. Rozpoczyna się w Rzymie, skąd prowadzi przez Asyż, Florencję, Padwę, Mariazell i Wiedeń do Krakowa.

\section{NOWE FORMY PIELGRZYMOWANIA I TURYSTYKI RELIGIJNEJ}

Wspomniany renesans szlaków pielgrzymkowych wpływa na niesłabnącą popularność pieszego pielgrzymowania w Polsce - zarówno tradycyjnymi szlakami maryjnymi, Drogą św. Jakuba, jak i nowymi szlakami związanymi z kultem świętych i błogosławionych. Pielgrzymowanie piesze Polaków w zorganizowanych grupach do narodowego sanktuarium Matki Bożej Częstochowskiej na Jasnej Górze jest stale fenomenem w chrześcijańskiej przestrzeni pielgrzymkowej. W ostatnich latach do jasnogórskiego sanktuarium przybywa pieszo ponad 120 tys. osób (w 2018 r. było to 124 tys. w 255 zorganizowanych grupach) (Jasna Góra, 2019). Nową inicjatywą w pieszym pielgrzymowaniu w Polsce i w ,wewnętrznej podróży, która pozwala spojrzeć w głąb siebie i uczy pokory" jest Ekstremalna Droga Krzyżowa (EDK) (Ekstremalna Droga Krzyżowa, 2019). EDK to praktyka religijna polegająca na indywidualnym pokonywaniu w nocy (z reguły w ostatni piątek Wielkiego Postu) jednej z kilkuset tras liczących od 40 do 133 km; w trakcie tej wędrówki uczestnik kontempluje poszczególne stacje drogi krzyżowej. Pierwsza Ekstremalna Droga Krzyżowa została zorganizowana w 2009 r. na trasie z Krakowa do Kalwarii Zebrzydowskiej. O sukcesie tej religijnej inicjatywy najlepiej świadczą dane o frekwencji: w 2014 r. w EDK uczestniczyło 6 tys. osób, w 2015 r. - 12 tys., w 2016 r. - 40 tys., w 2017 r. -60 tys., a w 2018 r. -80 tys. (Ekstremalna Droga Krzyżowa, 2019). Na wzór Ekstremalnej Drogi Krzyżowej w Lublinie i w Alwerni przed świętami Bożego Narodzenia organizowana jest Ekstremalna Droga do Betlejem. Z kolei od 2015 r. księża jezuici organizują tzw. Drogę Abrahama - ekstremalną pielgrzymkę dla mężczyzn. Idea tej wyprawy opiera się na jezuickiej próbie pielgrzymiej, nazywanej też „próbą żebraczą". Uczestnicy Drogi Abrahama wyruszają na jedną z kilku proponowanych tras bez pieniędzy, kart kredytowych, telefonów, rezerwacji noclegów (Droga Abrahama - pielgrzymka dla mężczyzn, 2018). W wielu regionach Polski w ciągu roku organizowane są również nocne pielgrzymki do sanktuariów (np. z Przemyśla do Kalwarii Pacławskiej, z Miedniewic do Niepokalanowa, z Suwałk do Studzienicznej).

Wraz z rozwojem sieci szlaków i ścieżek rowerowych w Polsce obserwuje się rosnącą popularność podróży i pielgrzymek rowerowych. Pielgrzymki tego typu są organizowane w Polsce od kilkudziesięciu lat, jednak w ostatnim 20-leciu rejestruje się wyraźny rozwój rowerowych podróży o charakterze religijnym i religijno-poznawczym (dla przykładu w 2018 r. na Jasną Górę przybyły 133 grupy rowerowe, podczas gdy w $2001 \mathrm{r}$. były to zaledwie 32 pielgrzymki) (Szlaki pielgrzymkowe, 2019). W polską przestrzeń pielgrzymowania wpisały się także pielgrzymki narciarskie (Pielgrzymka Narciarska Beskidzką Drogą św. Jakuba), kajakowe (np. Prawosławna Kajakowa Pielgrzymka Gródek-Supraśl; procesja wodna na rzece Supraśl z Nowodworc do Wasilkowa; procesja wodna rzeką Drwęcą z figurą Matki Bożej Łąkowskiej - z Nowego Miasta Lubawskiego do Łąk Bratiańskich) i pielgrzymki łodziami po rzekach i jeziorach (m.in. z parafii św. Zygmunta w Słomczynie do katedry w Płocku; z Nadola do Lubkowa przez Jezioro Żarnowieckie na odpust św. Anny w Żarnowcu). Nie traca na popularności również znane od wieków pielgrzymki konne (np. do sanktuariów w Kalwarii Zebrzydowskiej i na Jasną Górę) oraz Morska Pielgrzymka Rybaków na odpust św. św. Apostołów Piotra i Pawła w Pucku, która organizowana jest nieprzerwanie od 1981 r., jednak początkami sięga 1217 r. (Micun-Gusman, 2017).

Nowymi inicjatywami są pielgrzymki karawaningowe, nordic walking, na hulajnogach, rolkach i nartorolkach. Coraz częściej szlaki pielgrzymkowe w Polsce są przestrzenią rywalizacji i modlitwy wśród biegaczy indywidualnych i sztafetowych (m.in. Pielgrzymka Biegowa na Jasną Górę, Małopolski Bieg Drogą św. Jakuba, Półmaraton Jakubowy w Olsztynie). Liczba tego typu wydarzeń o charakterze sportowo-religijnym z każdym rokiem szybko rośnie - dla przykładu w 2001 r. na Jasną Górę przybyło 7 pielgrzymek biegowych, a uczestniczyło w nich 150 osób, zaś w 2018 r. było to już 16 grup skupiających 440 osób. Dużą frekwencją cieszą się także pielgrzymki motocyklistów, zwłaszcza na rozpoczęcie i zakończenie sezonu motocyklowego $\mathrm{w}$ wielu sanktuariach (m.in. Dębowiec, Gietrzwałd, Jasna Góra, Jodłówka, Licheń, Lutogniew, Kalwaria Pacławska, Markowice, Mikstat, Święty Krzyż, Wambierzyce). Dla przykładu w zorganizowanym 6-7 kwietnia 2019 r. XVI Motocyklowym Zlocie Gwiaździstym im. ks. ułana Zdzisława Peszkowskiego na Jasną Górę, inaugurującym sezon motocyklowy, do sanktuarium Matki Bożej Częstochowskiej przybyło ponad 50 tys. motocyklistów z całego kraju (Mototour, 2019).

Należy również podkreślić, że dzięki rosnącej liczbie połączeń przewoźników lotniczych niskokosztowych w Polsce $z$ każdym rokiem rośnie liczba uczestników pielgrzymek lotniczych. Z tego też m.in. względu Polacy są jedną z najczęściej przybywających nacji do głównych sanktuariów w Europie - np. w 2018 r. do sanktuarium Matki Bożej w Fatimie przybyło w grupach zorganizowanych 11928 Polaków, co plasowało polskich pątników na drugim miejscu, po Hiszpanach, wśród zagranicznych pielgrzymów (Santuário de Fátima, 2019). 


\section{ZMIANY W STRUKTURZE SPOŁECZNEJ GRUP ODWIEDZAJĄCYCH OŚRODKI PIELGRZYMKOWE W POLSCE}

W ostatnim 20-leciu obserwuje się także zmiany w społecznej strukturze grup pielgrzymkowych oraz turystycznych odwiedzających ośrodki pielgrzymkowe w Polsce. W wielu ośrodkach zamiast tradycyjnych pielgrzymek stanowych, np.: służby zdrowia, nauczycieli, rolników, pracowników zakładów pracy, organizowane są wyprawy nowych grup pielgrzymkowych: motocyklistów, strażaków, dzieci pierwszokomunijnych, niesłyszących, amazonek, anonimowych alkoholików, bezdomnych, seniorów. W większości sanktuariów o randze co najmniej diecezjalnej obserwuje się stały wzrost indywidualnego ruchu pielgrzymkowego - weekendowej turystyki religijnej. W sezonie pielgrzymkowym, przy dobrej pogodzie $\mathrm{w}$ weekendy i w dni świąteczne, do tych sanktuariów przybywają setki pielgrzymów indywidualnych (najczęściej rodzin z dziećmi), którzy uczestniczą we mszy świętej, a następnie wypoczywają w pobliskim regionie. Rozwojowi tego typu podróży o charakterze religijno-wypoczynkowym i religijno-poznawczym sprzyja przede wszystkim rozbudowa infrastruktury turystycznej (bazy gastronomicznej i noclegowej) w ośrodkach pielgrzymkowych i poprawa dostępności komunikacyjnej, a także wspomniany już rozkwit nowych szlaków religijnych, kulturowych (np. Szlaku Architektury Drewnianej, Szlaku Cysterskiego, Szlaku Piastowskiego) oraz szlaków turystyki kwalifikowanej (bardzo dobrą egzemplifikację $\mathrm{w}$ przypadku szlaków rowerowych stanowi szlak Green Velo, który prowadzi do wielu sanktuariów o randze ponadregionalnej i lokalnej).

Turystów religijnych oraz pielgrzymów do sanktuariów przyciągają - oprócz stałych nabożeństw i uroczystości - organizowane w nich obrzędy, misteria, odpusty i święta religijne, jak np. misteria Męki Pańskiej w sanktuariach w Kalwarii Zebrzydowskiej, Kalwarii Pacławskiej, Piekarach Śląskich, Wejherowie i Górce Klasztornej, ale też Konkurs Lipnickich Palm i Rękodzieła Artystycznego w Lipnicy Murowanej, święta bacowskie - redyk wiosenny i jesienny w sanktuarium Gaździny Podhala w Ludźmierzu, czy Jerozolimskie Misterium „Pogrzeb Jezusa” w sanktuarium św. Kazimierza w Krakowie.

\section{7. „WAKACJE” I URLOPY W KLASZTORACH ORAZ PUSTELNIACH}

Jednym z nowych trendów zauważalnych $\mathrm{w}$ turystyce religijnej w Polsce są pobyty urlopowe i wakacyjne w klasztorach, pustelniach oraz domach rekolekcyjnych. Ta oferta podróżowania i spędzania wolnego czasu kie- rowana jest do osób poszukujących wyciszenia, odpoczynku od codziennych obowiązków i obciążeń zawodowych, a także uwikłanych w uzależnienia cywilizacyjne. W krajach Europy Zachodniej „wakacje” i urlopy w klasztorach obejmują zróżnicowany pakiet: modlitewną ciszę, kursy kulinarne pozwalające na zgłębienie tajników kuchni zakonnej, uczestnictwo w stałych punktach dnia życia zakonników/zakonnic - wczesna pobudka, modlitwa, praca, spanie w klasztornej celi, skromne posiłki (Mróz, Mróz, 2013). W Polsce tego typu oferta odpoczynku i rekolekcji w obiektach sakralnych jest zróżnicowana i rozbudowywana. Stałym punktem programu jest „cisza” - terapia Salus per silentium (Zdrowie przez ciszę).

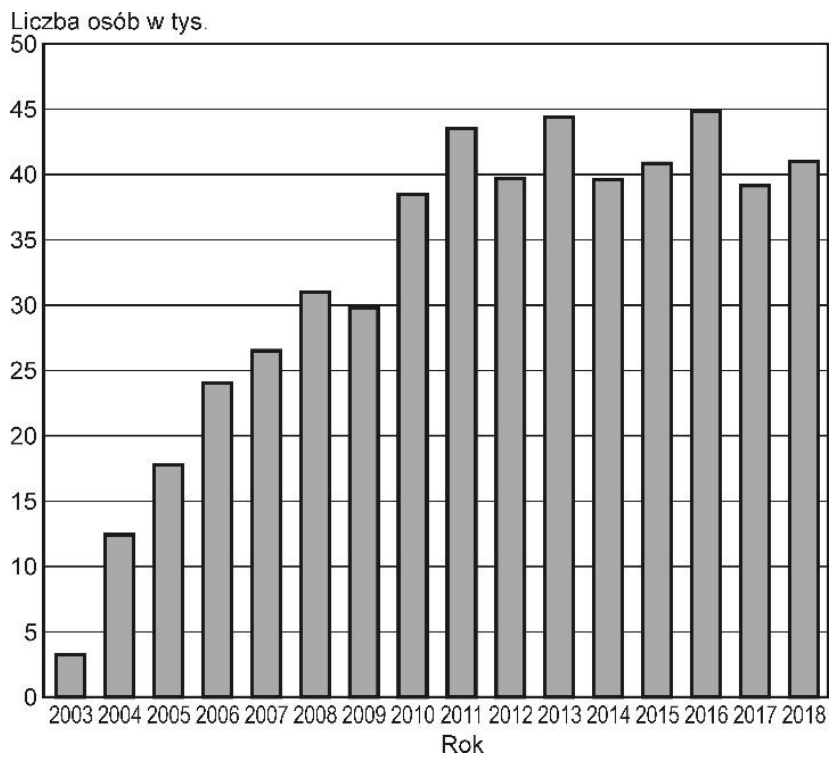

Rysunek 4. Zorganizowany ruch turystyczny do Pustelni Złotego Lasu w Rytwianach w latach 2003-2018 Źródło: opracowanie autora

Osoby wybierające urlop w klasztorze mogą włączyć się w rytm życia wspólnoty zakonnej, pogłębić doświadczenie modlitwy, porozmawiać z duszpasterzem, pospacerować po klasztornych ogrodach, poczytać dzieła w bibliotece klasztornej. Lista ośrodków oferujących urlop w klasztorach i domach rekolekcyjnych w Polsce z każdym rokiem się powiększa. Obecnie do najpopularniejszych miejsc tego typu należą: Pustelnia Złotego Lasu w Rytwianach (rys. 4), pokamedulski klasztor w Wigrach, klasztor oo. Kamedułów na Bielanach w Krakowie, klasztor oo. Benedyktynów w Tyńcu, klasztor oo. Marianów w Stoczku Klasztornym, Dom Pielgrzyma w Czernej, Karmelitański Dom Modlitwy Trójcy Przenajświętszej w Piotrkowicach, Dom Rekolekcyjno-Konferencyjny Księży Pallotynów „Wieczernik” w Świętej Katarzynie w Górach Świętokrzyskich, dominikański dom rekolekcyjny w Korbielowie, pauliński dom pielgrzyma w Leśnej Podlaskiej oraz klasztor Kamedułek w Złoczewie (por. Mróz, Mróz, 2013). Należy również 
podkreślić, że w ostatnich latach wiele zgromadzeń zakonnych w Polsce przygotowało bogatą ofertę rekolekcji i dni skupienia, które organizowane są przez cały rok w zakonnych domach rekolekcyjnych.

\section{PODSUMOWANIE}

Zawarte $\mathrm{w}$ niniejszym artykule rozważania pozwoliły stwierdzić, że na początku XXI w. - a więc w ostatnim 20-leciu - nastąpił wyraźny rozwój turystyki religijnej oraz nowych form pielgrzymowania w Polsce. Jest to efekt wielu czynników - nie tylko religijnych, ale także ekonomicznych, społeczno-kulturowych i historycznych. W ostatnich 18 latach w przestrzeni pielgrzymkowej Polski obserwuje się zjawisko renesansu średniowiecznych szlaków pielgrzymkowych (Droga św. Jakuba, Jeruzalem Way), powstawania nowych szlaków pielgrzymkowych i pielgrzymkowo-kulturowych, rozwoju nowych form pielgrzymowania i turystyki religijnej, zmian w społecznej strukturze grup odwiedzających ośrodki pielgrzymkowe w Polsce, a także rosnącą popularność pobytów urlopowych i wakacyjnych $\mathrm{w}$ klasztorach, pustelniach oraz domach rekolekcyjnych.

Wzrost popularności podróży o charakterze religijnym i religijno-poznawczym w Polsce nie osłabia nasilone zjawisko sekularyzacji życia publicznego i postępujący proces laicyzacji społeczeństwa polskiego (według badań Instytutu Statystyki Kościoła Katolickiego w 2017 r. 38,3\% zobowiązanych katolików uczestniczyło w niedzielnej mszy św., a w 2001 r. wskaźnik ten wynosił 46,8\%) (Instytut Statystyki Kościoła Katolickiego, 2019). Jeśli dodamy do tego rejestrowany wzrost liczby pielgrzymów i turystów z zagranicy $\mathrm{w}$ polskich sanktuariach, to można przypuszczać, że w najbliższych latach Polska umocni w Europie pozycję wiodącego kraju pod względem migracji pielgrzymkowych i turystyki religijnej. Będą temu sprzyjać zapewne zbliżające się jubileusze - m.in. 100-lecie urodzin Karola Wojtyły, a przede wszystkim Rok Święty, który przypada w 2025 r.

\section{PRZYPISY}

${ }^{1}$ W ostatecznej weryfikacji listy sanktuariów Pańskich w Polsce, obok materiałów źródłowych (głównie schematyzmów, informatorów oraz czasopism diecezjalnych i prowincjalnych), bardzo pomocne okazały się wykazy sanktuariów w poszczególnych diecezjach, jakie autor otrzymał ze wszystkich kurii metropolitalnych i diecezjalnych.

${ }^{2}$ Caminowicz - przyjęte już w literaturze przedmiotu określenie „osoby podróżującej (pieszo, rowerem, konno, kajakiem lub w sposób związany z innymi formami aktywności) indywidualnie lub grupowo Drogą św. Jakuba i wyróżniającej się charakte- rystycznymi dla Camino de Santiago atrybutami, m.in. posiadaniem muszli, laski pielgrzymiej, kapelusza lub paszportu pielgrzyma (credencial del peregrino)" (Mróz, 2018, s. 36).

\section{BIBLIOGRAFIA}

Bagiński, R., Kamiński, J. Opaliński, T. (red.) (2012). Sanktuaria miejsce pielgrzymkowe diecezji płockiej. Płock: Płocki Instytut Wydawniczy.

Datko, A. (2014). Sanktuaria i pielgrzymki. W: Kościół katolicki w Polsce 1991-2011. Rocznik statystyczny (s. 220-230). Warszawa: Instytut Statystyki Kościoła Katolickiego SACi Główny Urząd Statystyczny.

Droga Abrahama - pielgrzymka tylko dla mężczyzn. Pobrane z: http://jezuici.pl/2018/03/droga-abrahama-pielgrzymkadla-mezczyzn/ (10.04.2019).

Dyrektorium o pobożności ludowej i liturgii. Zasady i wskazania (2003). Poznań: Wydawnictwo Pallottinum.

Ekstremalna Droga Krzyżowa. Pobrane z: http://edk.org.pl (20.04.2019).

Estadísticas. Pobrane z: http://oficinadelperegrino.com/estadisticas/ (13.04.2019).

Instytut Statystyki Kościoła Katolickiego SAC. Pobrane z: http:/ / iskk.pl (22.04.2019).

Jackowski, A. (2003). Święta przestrzeń świata. Podstawy geografii religii. Kraków: Wydawnictwo Uniwersytetu Jagiellońskiego.

Jackowski, A., Bilska-Wodecka, E., Sołjan, I. (2014). Pilgrimages and religious tourism in Poland in the $21^{\text {st }}$ century - Current situation and perspectives for development. Zeszyty Naukowe Uniwersytetu Szczecinskiego. Ekonomiczne Problemy Turystyki, 4 (28), 253-270.

Jasna Góra. Pobrane z: http://jasnagora.pl (15.04.2019).

Kodeks Prawa Kanonicznego: przektad polski zatwierdzony przez Konferencję Episkopatu (1984). Poznań: Wydawnictwo Pallottinum.

Krogmann, A., Šolcová, L., Mróz, F., Mróz, Ł. (2013). Pielgrzymowanie Polaków i Słowaków Drogą św. Jakuba na początku XXI w. Peregrinus Cracoviensis, 24, 137-162.

Manikowska, H. (2002). Badania nad kultem św. Jakuba na ziemiach polskich - problemy i perspektywy. W: R. Knapiński (red.), Kult św. Jakuba Większego Apostoła w Europie Środkowo-Wschodniej (s. 9-24). Lublin: Towarzystwo Naukowe Katolickiego Uniwersytetu Lubelskiego.

Margry, P.J. (2015). To be or not to be... a pilgrim. Spiritual pluralism along the Camino Finisterre and the urge for the end. W: C. Sánchez-Carretero (red.), Heritage, pilgrimage and the Camino to Finisterre. Walking to the end to the world (s. 175-211). Cham: Springer International Publishing AG.

Matuszczyk, A., Własiuk, U. (2002). Pilnujcie mi tych szlaków: czyli o tym jak Ojciec Święty w polskie góry powraca. Przewodnik. Kraków: Wydawnictwo Radamsa.

Micun-Gusman, B. (2017). Msza na wodach Morza Battyckiego? Niezwykła Morska Pielgrzymka Rybaków. Pobrane z: http:// pomorskie.eu/-/msza-na-wodach-baltyku-niezwykla-morskapielgrzymka-rybakow (15.04.2019).

Mototour.pl. Pobrane z: http://mototour.pl (20.04.2019).

Mróz, F. (2014). Szlaki pielgrzymkowe w krajobrazie sakralnym Polski. W: M. Ostrowski, J. Partyka (red.), Krajobraz sakralny (s. 133-148). Kraków-Lwów: Uniwersytet Papieski Jana Pawła II w Krakowie.

Mróz, F. (2015). Droga św. Jakuba w Polsce - geneza i rozwój - w 10. rocznicę otwarcia pierwszego szlaku jakubowego. 
W: A. Wyrwa (red.), Camino de Santiago. Szkice historyczne do peregrynacji $i$ dziejów kultu św. Jakuba Apostoła Większego (wydanie II) (s. 65-95). Lednica: Muzeum Pierwszych Piastów na Lednicy.

Mróz, F. (2016). Sanktuaria Kościoła rzymskokatolickiego w przestrzeni sakralnej Polski. W: J. Latosińska, J. Mokras-Grabowska (red.), Kultura i turystyka. Sacrum i profanum (s. 183-205). Łódź: Regionalna Organizacja Turystyczna Województwa Łódzkiego.

Mróz, F. (2018a). Szlak Maryjny - Światło ze Wschodu. Kraków: Instytut Dialogu Międzykulturowego im. Jana Pawła II w Krakowie.

Mróz, F. (2018b). Przedsiębiorczość jako czynnik rozwoju Camino de Santiago w Polsce. Przedsiębiorczość - Edukacja, 14, 292-312.

Mróz, F., Mróz, Ł. (2013). Nowe trendy w turystyce. W: R. Pawlusiński (red.), Wspótczesne uwarunkowania i problemy rozwoju turystyki (s. 105-119). Kraków: Instytut Geografii i Gospodarki Przestrzennej UJ

Mróz, F., Mróz, Ł. (2018). Sanktuaria i ośrodki kultu św. Jakuba w sieci Camino de Santiago w Polsce. W: P. Roszak, F. Mróz, Ł. Mróz (red.), Duchowość i przestrzeń w kontekście Camino de Santiago (s. 151-178). Kraków: Wydawnictwo "Czuwajmy”.
Mróz, Ł. (2018). Droga św. Jakuba w Polsce. Przeworsk-Rzeszów: Wydawnictwo Edytorial.

Onorato, G., Rizzi, P. (2017). Il turismo culturale e la Via Francigena. W: G. Onorato, P. Rizzi (red.), Turismo, Cultura e Spiritualità. Rifl essioni e progetti intorno alla Via Francigena (s. 55-68). Milano: EDUCatt.

Pokojska, W., Pudełko, A. (2016). Światowe Dni Młodzieży w liczbach. Podsumowanie. W: E. Bogacz-Wojtanowska, Ł. Gaweł, A. Góral (red.), Światowe Dni Młodzieży 2016 jako fenomen społeczny, kulturowy i religijny (s. 25-43). Kraków: Stowarzyszenie Gmin i Powiatów Małopolski.

Santuário de Fátima. Pobrane z: http:/ / fatima.pt (10.03.2019).

Szlaki papieskie w Polsce. Pobrane z: http://szlakipapieskie.pl (10.03.2019).

Szlaki pielgrzymkowe. Pobrane z: http://www.jasnagora.com/ tematy/Statystyki\%20pielgrzymkowe/temat_61 (15.04.2019).

Tourism can protect and promote religious heritage (2014). Pobrane z: https://media.unwto.org/press-release/2014-12-10/tourismcan-protect-and-promote-religious-heritage (15.04.2019).

Artykuł wpłyną: 25 maja $2019 \mathrm{r}$. Zaakceptowano do druku: 15 lipca $2019 \mathrm{r}$. 